\title{
Proses Kreativitas dan Apresiasi Seni Dalam Pembelajaran Seni Tari Bagi Mahasiswa PIAUD UIN Sunan Ampel Surabaya
}

\author{
Lisa Alistiana*1 \\ 'Sekolah Tinggi Aagama Islam Taruna Surabaya \\ e-mail: lisa.fifafi@gmail.com
}

Submitted: 10-07-2020Ｒevised : 18-08-2020Ａccepted: 15-09-2020

\begin{abstract}
This study aims to develop creativity and appreciation of art in learning dance for students of UIN Sunan Ampel Surabaya PIAUD. Learning dance is very useful for PIAUD students because it can improve the ability to learn dance in art appreciation activities. Creativity in this research is to create a new thing in individual learning. In general, creativity and appreciation lead to the process of moving that drives someone in an action. Desires that must continue to be fostered for the process of learning dance one of them with a form of appreciation, because in the form of appreciation of art contains a beauty or aesthetic dance moves, as well as expression in learning dance know that dance creations also contain a beauty. The process of dance work will be an aesthetic experience for students who are in line with their educational interests through learning dance. This process is carried out continuously so that the appreciation of PIAUD students towards dance as expected and will increase and have creativity towards learning dance when they become kindergarten teachers.
\end{abstract}

Keywords: creativity, art appreciation, dance art, dance education

https://doi.org/10.31538/attadrib.v3i2.106

How to Cite Alistiana, L. (2020). Proses Kreativitas dan Apresiasi Seni Dalam Pembelajaran Seni Tari Bagi Mahasiswa PIAUD UIN Sunan Ampel Surabaya. Attadrib: Jurnal Pendidikan Guru Madrasah Ibtidaiyah, 3(2), 19-25

\section{INTRODUCTION}

Pendidikan pada dasarnya adalah untuk membentuk karakter bangsa yang bermartabat dalam mencerdaskan kehidupan bangsa. Hal tersebut sesuai dengan tujuan dan fungsi pendidikan nasional yang tertuang dalam undang-undang Sistem Pendikan Nasional Tahun 2003 Bab 2 Pasal 3, yaitu pendidikan nasional yang berfungsi untuk mengembangkan kemampuan dan membentuk watak serta peradaban bangsa yang bermartabat dalam rangka mencerdaskan kehidupan bangsa dengan tujuan untuk mengembangkan potensi peserta didik agar menjadi manusia yang beriman dan bertakwa kepada Tuhan Yang Maha Esa, berakhlak mulia, sehat, berilmu, cakap, kreatif, mandiri, dan menjadi warga negara yang demokratis serta bertanggung jawab (Depdiknas, 2003). Dalam undang-undang tersebut salah satu tujuan dari pendidikan adalah mengembangkan potensi peserta didik agar menjadi manusia yang kreatif.

Definisi kreatif sendiri pada hakikatnya adalah penemuan sesuatu yang baru yang sifatnya inovatif, menarik, dan berguna. Menurut (Munandar, 1992) kreatifitas adalah hasil dari interaksi antara individu dan lingkungannya. Seseorang mempengaruhi dan dipengaruhi oleh lingkungan dimana ia berada, dengan demikian baik di dalam individu maupun di dalam lingkungan dapat menunjang atau dapat menghambat upaya kreatif. Impilikasinya ialah bahwa kemampuan kreatif dapat ditingkatkan melalui sebuah pendidikan. 
Kreatifitas disini menjadi dasar perilaku mahasiswa PIAUD, karena kreativitas melibatkan sebuah pemikiran, keyakinan, tujuan dan penggambaran diri yang dimililiki setiap mahasiswa. Ktrativitas akan berubah seiring dengan perkembangan manusia. Supriyadi dalam Yeni Rachmawati dan Euis Kurniati (2005, p.15) menyatakan bahwa kreativitas merupakan kemampuan seseorang agar melahirkan sesuatu hal yang baru, berupa sebuah gagasan ataupun sebuah karya nyata yang sangat berbeda dengan apa yang telah ada. Melalui kreativitas mahasiswa PIAUD nantinya akan menjadi calon guru yang mempunyai kemampuan berfikir tinggi dan bisa berkreativitas agar menjadi calon guru PIAUD yang kreatif.

Salah satu pembelajaran yang dapat mengembangkan potensi diri dan kreativitas peserta didik adalah pembelajaran seni tari. Pembelajaran seni tari sangat berpengaruh dalam perkembangan emosi, karena pembelajaran seni tari tidak menuntut trampil dalam mencari sebuah gerak, tapi menguasai emosi dan pikiran dalam diri seseorang. Unsur-unsur dalam seni tari dilihat dari mahasiswa yang sedang menari, karena dalam membawakan sebuah gerak tari, diharapkan mempunyai penguasaan jiwa atau emosi yang sesuai dengan gerakan secara pola pikir. Jika dilihat tari memang sebagai kegiatan namun, seni tari juga sedikit banyak untuk melatih kepekaan rasa dan penangkapan daya pikir.

Menurut Soedarsono, yang dimaksud dengan tari adalah ekspresi jiwa manusia yang diungkapakan melalui gerak-gerak ritmis yang indah (Soedarsono, 1978 : 3). Komponen utama tari adalah tubuh sebagai media pengungkapan ekspresi, sehingga siapapun bisa belajar menari, baik itu menari dalam pendidikan formal maupun non formal karena Tari dalam pendidikan pada umumnya memberikan kesempatan pada setiap orang untuk merasakan bahwa tari dapat mempengaruhi perkembangan dan pertumbuhan jiwa seninya (Doubler, 1959).

Pembelajaran seni tari mempunyai pengaruh yang sangat penting terhadap pembentukan kepribadian dan tingkah laku, mahasiswa diupayakan mengenalkan nilai seni tari, karena umumnya tujuan pemebelajaran seni tari nantinya mampu menikmati, menghayati, memahami, dan menarik manfaat dari pembelajaran seni tari, serta memiliki sikap kebersamaan dan tenggang rasa, bertanggung jawab sehingga dapat membawa diri dalam pergaulan (Hidajat, 2005). Pembelajaran seni tari sangat pengaruh untuk perkembangan individu dan prilaku setiap orang, karena dengan pembelajaran seni tari akan menyatukan sebuah pengalaman setiap orang. Baik itu pengalaman pribadi yang tidak sengaja dan disengaja. secara umum dapat mempengaruhi tingkah laku serta kepribadian seseorang. Dalam Pembelajaran seni tari tidak hanya orang yang punya pengetahuan semata namun mendidik sesorang agar terarah dan bertingkah laku dengan baik.

Pembelajaran seni tari di kurikulum PIAUD UINSA adalah salah satu mata kuliah yang diberikan pada mahasiswa di semester 3 (tiga). Kompetensi yang diinginkan dalam matakuliah ini mahasiswa memahami pengertian tentang tari, pengetahuan dasar tari, berkreativitas dan berapresiasi melalui tari. Materi perkuliahan Pembelajaran Seni Tari adalah materi yang mendukung mahasiswa untuk melakukan proses kreativitas, apresiasi, membuat karya tari untuk anak usia dini dan ditampilkan dalam sebuah pagelaran yang di apresiasi, calon guru PIAUD, dan masyarakat pada umumnya.

Apresiasi menurut Gove (Dostia dan Aminudin, 1987) yaitu suatu mengenal seni dengan perasaan dan batin terhadap seni yang dikenal untuk memahami nilai-nilai estetika atau keindahan yang diungkapka oleh seniman. Pendapat Smith (Sutopo, 1989) mengatakan apresiasi proses memahami sebuah nilai karya seni yang dapat dihargai, dan paham apa makna yang terkadung didalamnya. pemahaman tentang apresiasi dan ekspresi dalam kreasi seni seperti yang telah di bahas, bahwa dihubungkan dengan pembelajaran seni tari hubungannya adalah pencapaian pendidikan estetika.

Materi yang diberikan dalam perkuliahan secara praktik dan teori. Materi praktik melibatkan mahasiswa agar mahasiswa mempunyai pengalaman dan ide kreatif sedangkan matakuliah teori mahasiswa mengenal dan memahami sebuah karya tari. Pembelajaran seni tari di PIAUD sistem pembelajarannya yaitu dosen memberikan penjelasan ragam gerak dan melihat audio visual tari untuk anak usia dini yang sumber geraknhya dari keseharian dilinguknagan sekitar seperti gerak 
hewan dan tumbuhan, setelah itu mahasiswa diharapkan untuk berkreativitas dan mengapresiasi agar bisa mengembangkan ide yang kreatif.

Harapan dalam matakuliah ini mahasiswa agar mampu mengembangkan kreatifitas. Dengan langkah tersebut mahasiswa masih perlu memperkuat strategi pembelajaran yang tepat dan sangat efektif, agar tertarik, sehingga pembelajaran seni tari materinya dapat tersampaikan dan dapat dicapai. Kenyataannya mahasiswa kurang berkreatovitas dalam prosese pembelajaran seni tari di kelas. Hal ini dikarenakan dosen lebih sering menyampaikan materi dengan menggunakan model demonstrasi. Untuk mengatasi mahasiswa yang kurang semangat maka dosen memberikan kesempatan kepada mahasiswa sesering mungkin agar mahasiswa mendapat sebuah pengalaman mengapresiasi seni tari secara langsung dan secara tidak langsung.

\section{METHOD}

Penelitian ini menggunakan metode kualitatif, Menurut pendapat Kirk dan Miller (1986:9) yang dimaksud dengan penelitian kualitatif adalah tradisi tertentu dalam ilmu pengetahuan sosial yang secara fundamental bergantung pada pengamatan manusia pada kawasannya sendiri dan berhubungan dengan orang-orang tersebut dalam bahasanya dan dalam peristilahannya. Jadi penyusunan kata-kata dalam penelitian ini dengan menggunakan bahasa dan istilah peneliti sendiri-sendiri dengan mengaitkan teori-teori yang sudah ada.

Pendekatan penelitian yang digunakan dalam penulisan ini adalah deskripsi analisis kualitatif. Yaitu mendeskripsikan dan menganalisis proses kreativitas dan apresiasi seni dalam pembelajaran tari bagi mahasiswa PIAUD UIN Sunan Ampel Surabaya.

Latar penelitian yaitu prodi PIAUD UIN Sunan Ampel Surabaya. Subjek penelitiannya mahasiswa PIUD UIN Sunan Ampel Surabaya. Kreativitas mahasiswa membuat dosen harus kreatif dalam menciptakan pembelajaran yang unik dan menarik, sehingga mahasiswa tidak merasa bosan dan cepat menangkap materi yang disampaikan.

Sumber data yang utama dalam penelitian kualitatif adalah kata-kata dan tindakan, selebihnya adalah data tambahan seperti dokumen dan lain-lain (Lofland dalam Moleong, 1989:122). Kata-kata dan tindakan orang-orang yang diamati atau diwawancarai merupakan sumber data utama. Sumber data utama dicatat melalui catatan tertulis atau melalui perekaman video atau audio tape, pengambilan foto dan film. Sumber data yang utama dalam penulisan ini berasal dari wawancara mahasiswa.

Instrumen Penelitian adalah alat mengumpulkan data seperti tes pada penelitian kualitatif. Adapun instrumen penelitian yang digunakan untuk memperoleh data dengan menggunakan pertanyaan-pertanyaan terkait dengan Proses Kreativitas dan Apresiasi Seni Dalam Pembelajaran Tari Bagi Mahasiswa PIAUD UIN Sunan Ampel Surabaya.

Teknik analisis data yang digunakan dalam penelitian ini adalah deskriptif kualitatif. Setelah data terkumpul, data tersebut akan dianalisis secara deskriptif. Analisis secara deskriptif digunakan untuk mendeskripsikan Proses Kreativitas dan Apresiasi Seni Dalam Pembelajaran Tari Bagi Mahasiswa PIAUD UIN Sunan Ampel Surabaya.

\section{HASIL DAN PEMBAHASAN}

\section{Result}

Menurut Kreiner dan Kinicki, kreativitas diartikan sebagai proses berimajinasi dan berketrampilan dalam bentuk produk, proses. Kreativitas adalah proses dalam mengembangkan sesuatu yang baru (Martopo,2006:213). Ada beberapa ciri orang yang kreatif yaitu orang yang memiliki ide baru, berani tampil, selalu ingin mencoba tidak takut akan ke (Soenarno,2006:11). Ciri-ciri ini sudah dimiliki oleh manusia yang di karuniakan oleh Allah, seperti pendapat (Santoso, 
2002:148) kreativitas adalah karakteristik yang dimiliki oleh setiap orang sebagai karunia yang di berikan Allah.

Dari berbagai pendapat diatas dapat disimpulkan bahwa kreativitas adalah kegiatan menyusun kembali berbagai ide yang dimiliki oleh mahsiswa untuk membentuk sebuh gerak tari yang baru dengan menggunakan pemikiran. Fungsi pemikiran adalah untuk mengatasi kesulitan yang jawabannya adalah sebuah kreativitas dari diri mahasiswa. Kemampuan dalam kreativitas merupakan karunia Allah SWT untuk mahkluknya agar dapat mengatasi masalah kehidupan.

Sesorang pasti mampu untuk berkretivitas agar menemukan beberapa hal baru, baik itu sebuah ide, gagasan dan sebuah karya yang berbeda dengan yang sudah ada (Munandar 1999: 33). Dengan begitu, mahasiswa PIAUD mampu untuk memberi sebuah ide ataupun gagasan dan karya baru untuk menerapkan pemecahan masalah dalam belajar menari. Pendapat lain juga, kreativitas itu adalah diibaratkan sebuah intan. Yang terus menurus diasah, akan semakin berkilau. Begitupun juga orang dia mampu menciptakan sesuatu yang baru maka orang tersebut akan mengasahnya dengan stimulasi dan modalnya adalah berfikir, (Muhammad 2010: 77).

Mahasiswa Piaud disini menciptakan karya tari untuk anak usia dini, proses dan ide gagasannya tersebut dapat menyelesaikan sebuah masalah dalam pembelajaran seni tari yang sebagai salah satu mata kuliah di PIAUD. Kreativitas dikembangkan melalui pembelajaran seni tari agar mahasiswa menjadi kreatif, dengan memberikan sebuah cerita, presentasi dan melihat sebuah pertunjukan maupun vidio tari, kemudian mahasiswa disuruh mengeksplor dalam bentuk gerak. Dimana gerak tersebut menggambarakan cerita dengan tokoh, peran bahkan gambaran yang ada dalam cerita ataupun vidio tari tersebut. Dengan begitu mahasiswa akan bisa mengembangkan dalam bentuk sebuah karya tari, dan diberikan kebebasan dalam membuat sesuatu karya dengan kreativitas mereka masing- masing.

Guru ataupun dosen yang efektif mempunyai banyak strategi dalam pembelajaran agar murid ataupun mahasiswa mau belajar dengan baik (Boekaerts, Pintrich, dan Zeidner, 2000; Stipek dalam Santrock, 2010). Para psikologi pendidikan percaya bahwa kreativitas itu mendorong dan memberikan kesempatan bagi peserta didik untuk belajar di dunia nyata, supaya mereka mempunyai kesempatan dan menemukan suatu hal yang baru dan sulit (Brophy dalam Santrock, 2010). Pendidik yang baik akan tau dan paham terhadap peserta didiknya dan mereka akan termotivasi dengan suatu hal yang sudah menjadi minatnya. pendidik yang baik akan selalu memberikan kesempatan kepada peserta didik untuk berfikir kreatif dan mendalam untuk proyek mereka sendiri (Runco dalam Santrock, 2010). Seni tari menjadi sebagai materi pendidikan yang sudah memasuki berbagai lingkungan lembaga pendidikan dan berkembang seiring dengan perkembangan ilmu pengetahuan dan teknologi, meski pun hingga saat ini konsep pendidikan seni tari yang telah dikembangkan oleh para pakar pendidikan seni belum maksimal (Hidajat, 2005).

\section{Discussion}

Metode yang digunakan dalam pelatihan pembelajaran seni tari untuk mahasiswa PIAUD. Satu diantaranya sebagai metode pokok, yaitu yang paling dominan dan yang dua sebagai pelengkap atau berfungsi sebagai pendukung metode pertama. Metode pokok dalam pembelajaran seni tari ini adalah Metode pengenalan yaitu memberikan gambaran secara langsung bagaimana bentuk tari yang sesungguhnya dengan menggunakan media Audio Visual. Media Audio Visual yaitu suatu media yang bisa menampilkan gerak, berisi vidio tari. Yang menjadi fokus dari penggunaan media ini adalah mahasiswa sekedar tau bagaimana ciri dari tari untuk anak usia dini itu seperti apa dan di apresiasi oleh mahasiswa.

Metode pendukung dalam pembelajaran tari ini adalah Metode Demonstrasi dan Metode Mengingat Birama atau Hitungan dalam Irama Tarian. Pada saat mahasiswa mencoba untuk berkreativitas baik itu membuat gerak dan menirukan tarian yang ada, dosen memberi pengarahan dan membetulkan apabila ada gerakan-gerakan yang kurang betul karena pada dasarnya mahasiswa bukan dari seorang penari namun awal untuk belajar tari. 
Materi gerak tari yang digunakan dalam pembelajaran tidak harus sma dengan gerak tari yang sudah ada ataupun tari yang sudah jadi sebagaimana tari itu untuk anak usia dini, (Depdikbud, 1997), pada dasarnya tujuan kegiatan ini tidaknya mengharapkan mahasiswa ahli ataupun pandai menari. Proses yang dipersiapkan dalam tari untuk anak usia dini disusun secara bertahap. Sebenarnya tidak ada perbedaan tahapan dalam proses pembuatan tari untuk anak usia dini, hanya saja ada perbedaan tema dan langkah-langkahnya, antara lain: (1) proses kretivitas, (2) improvisasi, (3) apresiasi.

Proses kreativitas. Pada proses kreativitas ini mahasiswa dipandu untuk mengamati lingkungan sekitarnya, dan mengamati vidio tari yang sudah ada dengan itu mahasiswa akan mendapatkan sebuah pengalaman, dan pengetahuan, dalam memahami objek. Mahasiswa akan menjadikan objek tersebut sebagai ide atau gagasan untuk menciptakan sebuah tari yang sangat sederhana. Proses kreativitas ini mahasiswa mengeksplorasi melalui lingkungan sekitar, melihat pertunjukan tari untuk anak usia dini, dan melihat vidio. Mahasiswa menggunakan eksplorasi agar mendapat kreativitas dengan lingkungan sekitar, melihat vidio agar mencari berbagai macam gerak untuk dapat melakukan gerak tari yang bisa di eksplor melalui lingkungan sekitar seperti Tumbuhan, Hewan, dan Binatang. Eksplorasi melalui binatang, Mahasiswa diberikan tugas agar mengemati binatang yang ada disekitarnya, dengan begitu mereka melakukan proses kreativitasnya bisa memperoleh gerak tari yang sudah dibuat. contoh cara seekor burung bisa terbang, ikan yang berenang dan ayam yang berjalan, dan makan, ataupun kelinci yang melompat. Proses kretivitas melalui dongeng dan buku cerita untuk anak. Ada banyak sekali dongeng ataupun cerita anak untuk dijadikan tari untuk anak, tema yang biasanya dipakai dalam tari biasanya mengangkat cerita legenda. Biasanya ada beberapa kategori yang bisa di ambil untuk proses kreativitas, diatarnya judul ataupun tema dalam cerita, jalan ceritany, suasananya dan karakteristik aktor atau tokoh yang bisa diambil dalam kesan atau pesan moral. Proses kreativitas dengan melihat lingkungan sekitar. Misalnya, di jalan raya, dapur, halaman rumah dll. agar ide itu muncul, kita bisa merangsang dengan rangsangan visual, dengar ataupun dengan meraba. mahasiswa juga bisa memakai objek yang dekat denga dirinya seperti mainan untuk anak sapu dan lain sebagainya.

Improvisasi. mahasiswa mencari sebuah gerakan yang sesuai dengan obyek yang sudah diamati. gerakan-gerakan yang dilakukan oleh mahasiswa secara spontan namun terkendali. Memanfaatkan improvisasi di maksimalkan dengan rangsangan musik atau sebuah property. Setelah itu adalah composing. Mahasiswa membuat sebuah gerakan yang sudah di dapat, dan memulai untuk menggabung dengan unsur-unsur yang bisa menunjang karya tari lain, sehinga akan menjadi sebuah karya tari yang utuh yang siap untuk ditampilkan.

Mahasiswa sudah penyusunan karya tari, maka mahasiswa dituntut agar kreatif, inovatif, bahkan teliti untuk mencari dan membuat gerak untuk anak usia dini. Karya Tari yang diciptakan harus mudah dipahami oleh anak usia dini dan menarik agar bisa berkreasi dan anak usia dini bisa berimajinasi. Misalnya tari Burung, didalam tari burung anak menirukan gerakan seperti mengepakan sayap. Mereka memakai property sayap yang digambarkan dengan terbang. Mahasiswa bergerak dengan kedua tangannya yang dikepakkan kesamping atas bawah seperti burung yang lagi terbang. Gerakan diikuti dengan gerakan kaki sambil lari kecil serta kepala menoleh kekanan dan kekiri. Gerakan nya diteruskan dengan meloncat dan tangan di pinggang badan menunduk seperti seekor burung yang lagi mencari makan.

Dari karakteristik tersebut, mahasiswa perlu tau bahwa tujuan melatih ketrampilan gerak dalam belajar menari untuk anak usia dini bukan yang utama, tetapi kita bisa mengembangkan kreativitas untuk anak usia dini agar mahasiswa mampu membuat karya tari dan berproses pembelajaran dalam bentuk tari maupun gerak dan lagu. Tujuan dari pembelajaran seni tari ini agar mahasiswa terbantu dalam membuat dan mengembangkan kemampuan mahasiswa dalam gerak tari.

Ada beberapa pemahaman yang didapat mahasiswa dalam pembelajaran seni tari yaitu, tujuan atau cara mengembangkan, kreativitas memberi peluang terhadap mahasiswa untuk 
berekspresi serta dapat mengembangkan pribadi anak usia dini dalam pembentukan pribadi secara individu sosial maupun budaya.

Langkah selanjutnya dalam apresiasi yang dilakukan adalah, dosen memberikan sebuah materi kepada mahasiswa secara kompleks dengan melihat dan menyaksikan sebuah vidio tari dan mahasiswa mengapresiasi. selanjutnya dipahami. Mahasiswa memahami secara tekstual dan kontekstual. Memahami secara tekstual adalah pemahaman tentang seni yang berhubungan dengan tarinya. Memahami secara kontekstual terkait segala sesuatu yang berkaitan dengan teks/materi tarinya. Memahami konteks ini hubunganya dengan keadaan yang muncul dalam tari, baik itu lingkungan sosial, yang hubungannya dengan kondisi sehari-hari.

Apresiasi menurut Gove (Dostia dan Aminudin, 1987) yaitu suatu mengenal seni dengan perasaan dan batin terhadap seni yang dikenal untuk memahami nilai-nilai estetika atau keindahan yang diungkapka oleh seniman. Pendapat Smith (Sutopo, 1989) mengatakan apresiasi proses memahami sebuah nilai karya seni yang dapat dihargai, dan paham apa makna yang terkadung didalamnya. pemahaman tentang apresiasi dan ekspresi dalam kreasi seni seperti yang telah di bahas, bahwa dihubungkan dengan pembelajaran seni tari hubungannya adalah pencapaian pendidikan estetika, tampaknya akan menjadi sarana ketersampaiannya.

Mahasiswa memahami teks tariannya. Pemahaman tekstual tersebut ada hubungannya dengan unsur dan gerak tari, tata rias dan busana serta musik. Analisis tari yang lain bisa dilihat dari gerak kepala, kaki, badan. Untuk riasnya bisa dipahami atau dilihat dari rias cantik dan karakter. Musik Iringan dapat dilihat dari luar dan dan dalam tubuh penari.

Rasa atau Penghayatan dalam tubuh penari, yang dipahami dalam rasa ini adalah kaitannya dengan penghayatan ataupun penjiwaan. Disini seorang penari mengekspresikan wajah ataupun gerak sesuai dengan cerita ataupun karakter tari yang akan ditarikan. Ekspresi dalam cerita tersebut misalnya cerita yang sesuai dengan tema, karakter dari tokoh cerita, baik itu karakter gagah, halus, maupun keras.

Mengevaluasi, yang dipahami dalam evaluasi berkaitan dengan penilaian. Penilaian disini dilihat dari bagus dan tidaknya. Yang dipahami dari bagus dan tidaknya hubungannya dengan penjiwaan kita. Dengan arti apakah tari itu bisa dipahami ataupun dinikmati dan apakah tari tersebut menimbulkan imajinasi dan mempunyai nilai budaya.

Selanjutnya membarikan apresiasi dan penghargaan seperti itu yang di maksud proses kreativitas dan apresiasi dalam pembelajaran seni tari. Dengan kreativitas dan apresiasi yang baik maka akan timbul ide dan konsep yang luar biasa. Sebagaimana jika mengapresiasi tari dari berbagai macam bentuk tari mahasiswa akan semakin banyak ide dan gagasan yang kreatif terkait dengan kreasi tari bahkan akan menemukan ide dan konsep yang berbeda-beda. Awal dari penemuan ide, gagasan ataupun konsep akan bisa menuangkan ide tersebut dalam bentuk gerak. Ide dan konsep setiap mahasiswa pasti berbeda adapun yang sama namun mengaplikasikan dan penuanganya masing-masing mahasiswa pasti berbeda. Contoh dalam mewujudkannya sebagai bentuk karya tari meski ide dan konsep bisa sama belum tentu digerak akan sama.

Suatu gerakan jika dihubung-hubungkan dari benak kita dengan keterkaitan ide dan konsep maka akan mendapat sesuatu hal yang baru. Dengan begitulah akan muncul berbagai gerakan yang bisa dirangkai sesuai dengan gambaran dari benak yang sudah sesuai dengan ide maupun konsep mahasiswa. Oleh karna itu kreasi tari setiap mahasiswa akan mendapatkan hasil tarian yang berbeda. Walaupun gambaran ataupun tema tarian itu sama dari menghubung-hubungkan itulah gerak tersebut akan mendapat gerak yang berbeda.

\section{KESIMPULAN}

Kreativitas mengacu pada proses yang diarahkan pada pencapaian tujuan. Kreativitas mempengaruhi proses pembelajaran seni tari, karena dalam kerativitas dapat mempengaruhi setiap perlakuan mahasiswa masing-masing dalam kreativitasnya mereka dapat menyelesaikan tugas berikutnya. Kreativias mahasiswa disini diarahakan pada kegiatan mengapresiasi vidio ataupun tampilan pertunjukan tari untuk anak usia dini 
Apresiasi dan kreasitivitas mahasiswa bisa dilihat dari pemahaman konsep mengapresiasi kreasi tari terlebih dahulu. Jika konsep apresiasinya dapat dipahami maka proses apresiasi dan kreativitas bisa diterapkan melalui pembelajaran seni tari. Hubungannya dengan itu maka langkah pembelajaran tari untuk anak usia dini melalui pendekatan proses kretivitas dan apresiasi. Adapun langkah pembelajaran seni tari untuk anak usia dini yang utama yaitu melalui sebuah pengenalan, menikmati, memahami sebuah materi, menghayati, dan menghubung-hubungkan gerak tari yang bisa dievaluasi dalam sebuah gerak tari yang utuh.

Tahap pembelajaran seni tari berawal dari mahasiswa mengembangkan ide dan konsep yang sudah dilihat ataupun didapat dalam mengapresiasi sebuah karta tari, kemudian mahasiswa menuangkan dan mengembangkan apresiasi tersebut dalam sebuah gerak tari yang sesaui ide dan konsep.

\section{ACKNOWLEDGMENT}

- UIN Sunan Ampel Surabaya

- Fakultas Tarbiyah dan Keguruan Prodi PIAUD UIN Sunan Ampel Surabaya

- Mahasiswa Prodi PIAUD UIN Sunan Ampel Surabaya

\section{BIBLIOGRAPHY}

Depdiknas. 2003. Undang-Undang Guru dan Dosen serta Standar Nasional Pendidikan Tahun 2005. Jakarta.Penerbit CV Tamita Utama.

Edi Setyowati, 1986. Pengetahuan Elemen Tari Dan Beberapa Masalah Tari. Jakarta: Direktorat Kesenian.

Sutopo, H.B, Metodologi Penelitian Kualitatif (Dasar teori dan terapannya dalam penelitian), Surakarta : Sebelas Maret University Press, 2002.

Muhammad, As'adi. 2010. Bila Otak Kanan dan Otak Kiri Seimbang. Jogjakarta: Diva Press

Munandar, Utami. 1999. Kreativitas dan Keterbakatan. Jakarta: PT. Gramedia Pustaka Utama

Hidajat, Robby. 2005. Menerobos Pembelajaran Tari Pendidikan. Malang: Banjar Seni Gantar Gumelar.

Senanro,Adi.2006.Creativity Games.Yogyakarta:Andi

Sutopo, H.B, Metodologi Penelitian Kualitatif (Dasar teori dan terapannya dalam penelitian), Surakarta : Sebelas Maret University Press, 2002.

Soedarsono. Djawa Bali; Dua Pusat Perkembangan Dramatari Tradisionel di Indonesia. Yogyakarta : Gadjahmada Universitas Press;1978:3 